\title{
PROPOSISI DALAM RANCAG SI PITUNG (STRUKTUR, MAKNA PREDIKATOR, DAN PERAN ARGUMEN)
}

\author{
Nicky Rosadi \\ Program Studi Pendidikan Ekonomi \\ Universitas Indraprasta PGRI Jakarta \\ nickyrosadi@gmail.com
}

\begin{abstract}
Abstrak
Penelitian ini bertujuan untuk mengetahui proposisi yang terdapat dalam Rancag Si Pitung. Penelitian ini menggunakan metode analisis deskriptif kualitatif dengan analisis isi. Objek pada penelitian ini adalah teks Rancag Si Pitung yang terdapat dalam buku Lagu Pesisiran Puisi-Puisi Betawi yang ditulis Ridwan Saidi dan diterbitkan oleh Bukupop yang bekerja sama dengan Badan Pemberdayaan Budaya Betawi pada 2008. Instrumen yang digunakan pada penelitian ini adalah peneliti sendiri yang dibantu dengan tabel analisis data dengan kriteria analisis melalui tiga pengamatan, yaitu struktur proposisi, makna predikator, dan peran argumen. Berdasarkan hasil analisis, ditemukan sebanyak 39,39\% struktur proposisi P + N1 + N2, 66,67\% predikator bermakna perbuatan, dan 29,68\% argumen yang berperan sebagai pelaku. Dengan demikian, dapat disimpulkan bahwa struktur proposisi yang banyak digunakan dalam Rancag Si Pitung adalah struktur predikasi inti, dengan predikator bermakna perbuatan, dan argumen yang berperan sebagai pelaku.
\end{abstract}

Kata Kunci: proposisi, struktur, makna predikator, peran argument

\begin{abstract}
This study aims to determine the proposition contained in Rancag Si Pitung. This research uses descriptive qualitative analysis method with content analysis. The object of this research is the Rancag Si Pitung text contained in Lagu Pesisiran Puisi-Puisi Betawi book which is written by Ridwan Saidi and published by Bukupop in collaboration with Badan Pemberdayaan Budaya Betawi in 2008. The instrument used in this research is the researcher himself who assisted with table analysis of data with criteria of analysis through three observations, there are the structure of propositions, the meaning of predicators, and the role of arguments. Based on the results of the analysis, found 39,39\% structure of proposition $P+N 1+N 2,66,67 \%$ predictor of action, and 29,68\% argument as the agent. Thus, it can be concluded that the structure of the widely used proposition in Rancag Si Pitung is the core predication structure, with meaningful predictions of deed, and the argument as the agent.
\end{abstract}

Keyword: proposition, structure, meaning of predicators, the role of arguments

\section{PENDAHULUAN}

Dalam memproduksi bahasa, penutur bahasa tidak begitu saja mengeluarkan kata-katanya. Penutur sebuah bahasa juga harus memiliki kemampuan dalam menyusun kata-kata yang kemudian diwujudkan dalam bentuk struktur klausa/kalimat. Kesalahan dalam menyusun struktur, maka akan menimbulkan kesalahan dalam penafsiran makna yang hendak disampaikan.

Pengetahuan dan kemampuan terkait pembentukan struktur ini disebut kompetensi. Kompetensi ini didapat dengan berbagai cara; bisa dimiliki secara alami ataupun dipelajari. Dimiliki secara alami, jika bahasa yang dikuasai merupakan bahasa ibu (B1). Akan tetapi dapat dipelajari, jika bahasa 
yang hendak dikuasai bukanlah bahasa ibu (B2). Kompetensi ini selanjutnya digunakan sebagai bekal untuk mewujudkan maksud yang hendak disampaikan dalam bentuk tulisan atau tuturan.

Perwujudan kompetensi ini dikenal dengan performansi. Dari performansi inilah akan dapat terlihat bagaimana kompetensi bahasa seseorang. Berdasar performansi ini jugalah, struktur bahasa yang terbentuk akan dapat dianalisis dengan mudah.

Perhatikan contoh (I) berikut:

$\begin{array}{lcc}\text { Amir } & \text { memanggil } & \text { Aminah } \\ \text { (nomina) } & \text { (verba) } & \text { (nomina) }\end{array}$

Dari contoh di atas, dapat terlihat bahwa Amir (nomina) adalah pelaku yang melakukan sesuatu, dalam hal ini memanggil (verba), sehingga dikategori-kan sebagai subjek. Sedangkan Aminah (nomina) adalah sasaran dari apa yang dilakukan subjek, sehingga dapat di-kategorikan sebagai objek. Meski Amir dan Aminah memiliki kelas kata yang sama, yaitu nomina, namun dalam perwujudannya tidak dapat saling menggantikan menjadi:

$\begin{array}{lll}\begin{array}{l}\text { Aminah } \\ \text { (nomina) }\end{array} & \begin{array}{l}\text { memanggil } \\ \text { (verba) }\end{array} & \begin{array}{l}\text { Amir } \\ \text { (nomina) }\end{array}\end{array}$

Contoh (II) di atas jelas memiliki makna yang berbeda dari contoh (I) sebelumnya. Perbedaan makna ini terletak pada penentuan subjek dan objeknya. Kata kerja pada dua contoh tersebut, memegang peranan penting terkait penentuan subjek dan objek. Siapa yang memanggil? Itulah subjek. Siapa yang dipanggil? Itulah objek. Hal ini mengindikasikan bahwa sejatinya, predikat memegang peranan penting terkait penentuan peran nomina-nomina yang ada di sekitarnya. Bandingkan dengan contoh (III) berikut ini:

Aminah dipanggil Amir (nomina) (verba) (nomina)

Contoh (III) memperlihatkan bahwa, meski Aminah (nomina) dalam perwujudannya dimunculkan di awal, perannya tetaplah sebagai sasaran, sehingga berkategori objek. Sedangkan subjek ditempati oleh Amir (nomina) yang bertindak sebagai pelaku. Penentuan pelaku dan sasaran ini dipengaruhi oleh relasi makna antara predikat dengan nomina di sekitarnya.

Relasi makna yang terjalin antara predikat dengan nomina-nomina yang ada dalam struktur bahasa ini dikenal dengan proposisi (Achmad HP, 2002: 108). Dalam proposisi, setiap kata yang menempati kategori predikat dikenal dengan predikator. Sedangkan nominanomina yang men-duduki peran tertentu dikenal dengan argumen. Peran argumen yang dihasil-kan, selanjutnya menentukan prioritas kemunculan nominanya dalam struktur proposisi. Predikator selalu menjadi inti perhatian dalam penulisan struktur proposisi.

Proposisi dapat ditemukan dalam tuturan/tulisan yang berwujud klausa ataupun kalimat, salah satunya ialah rancag. Rancag merupakan teknik penceritaan khas Betawi yang dibawakan dengan cara dipantunkan. Pantunan kisah ini juga diiringi oleh musik.

Salah satu rancag yang berkembang di kalangan masyarakat Betawi adalah Rancag Si Pitung. Atas dasar itulah, akan diteliti proposisi dalam Rancag Si Pitung (struktur, makna predikator, dan peran argumen). Penelitian terkait proposisi bukan berarti tidak dapat dilakukan pada teks lain, tetapi Rancag Si Pitung dipilih dalam penelitian ini karena dianggap teks ini lebih menarik untuk diteliti.

\section{Hakikat Proposisi}

Setiap konstruksi gramatikal mem-punyai relasi makna yang dikenal dengan proposisi. Proposisi ini 
terbentuk karena adanya keterkaitan antara predikat dengan nomina dalam suatu konstruksi gramatikal. Sebuah predikat pada konstruksi tersebut, memerlukan pembagian peran yang jelas dari nomina agar dapat mempertegas makna predikat itu sendiri. Selanjutnya, setiap kata yang menempati fungsi predikat disebut predicator, sedangkan nomina-nomina yang menduduki peran-peran tertentu sehingga mempertegas makna predikat disebut argumen.

Proposisi terjadi jika terdapat satu predikator yang bertemu dengan satu argumen atau lebih dalam sebuah konstruksi gramatikal. Hubungan inilah yang kemudian mempertegas makna predikator, apakah predikator ini bermakna perbuatan, proses, posisi, keadaan, atau identitas. Predikator ini dapat ditempati oleh kata yang berkategori verba, adjektiva, bahkan zero (0). Jika predikator dan peran argumennya telah diketahui, maka dapat disusun sebuah struktur yang dikenal dengan struktur proposisi.

Menurut Langacker (1972:98), struktur proposisi (propositional structure) digunakan untuk menandai representasi semantik sebuah kalimat yang disusun berdasarkan komponen proposisinya. Pembagian peran argumen yang didasarkan pada makna predikator, akan merepresentasikan prioritas urutan kemunculan argumen. Dari sinilah kemudian terwujud representasi semantik yang menjadi acuan pembentu-kan konstruksi gramatikal. Jika telah diketahui susunan representasi semantiknya, maka akan dapat dipahami berbagai variasi konstruksi gramatikal dengan struktur proposisi yang sama.

\section{Struktur Proposisi}

Dalam tata bahasa fungsional, subjek, objek (baik langsung maupun tidak langsung), dan pelengkap merupakan pendamping (argumen). Selanjutnya, bersama-sama predikat (predikator), argumen ini membentuk sebuah satuan (term) yang disebut predikasi inti (nuclear predication). Keterangan, yang juga disebut sebagai satelit (satellite), merupakan satuan lain yang bersama-sama dengan predikasi inti membentuk predikasi luasan (extended predication) (Dik, 1981:2526).

Perhatikan bagan berikut (Sudaryat, 2012: 20):

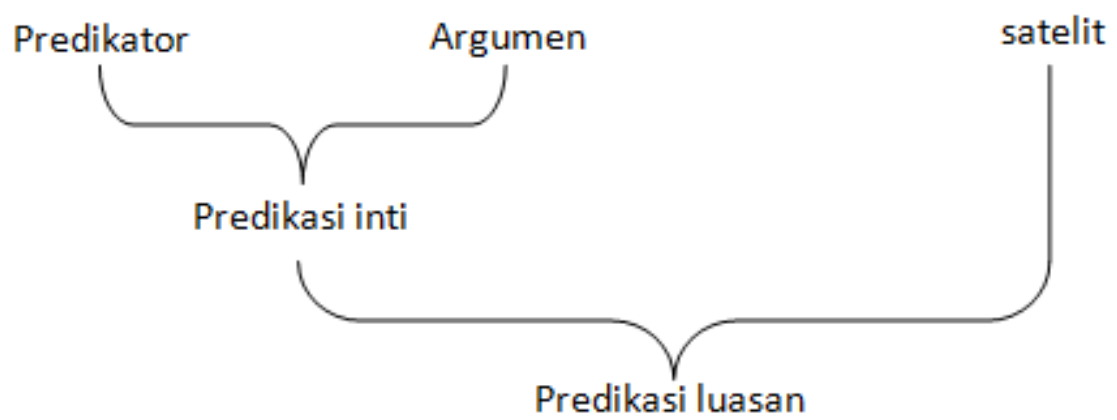

Bagan 1 skema predikasi

Sebagai contoh kalimat kemarin Jhon membuka pintu dengan kunci, merupakan predikasi luasan. Predikasi inti dalam kalimat ini terdiri atas predikator dan tiga argumen. Predikasi inti ini kemudian menjadi predikasi luasan karena terdapat tambahan unsur keterangan waktu/satelit. 
Predikator $(\mathrm{P})$ dari kalimat di atas adalah kata verba buka yang bermakna perbuatan. Nomina pertama, yaitu John, jika dihubungkan dengan predikator, berperan sebagai pelaku. Nomina kedua, yaitu pintu, jika dihubungkan dengan predikator, berperan sebagai tujuan. Selanjutnya nomina ketiga, yaitu kunci, jika dihubungkan dengan predikator, berperan sebagai alat. Oleh sebab itu, secara berturut-turut, John, pintu, dan kunci merupakan argumen 1 (N1), argumen 2 (N2), dan argumen 3 (N3). Sedangkan keterangan/satelit dalam kalimat di atas adalah konstituen kemarin.

Untuk dapat memperjelas penjabaran di atas, perhatikan bagan berikut.

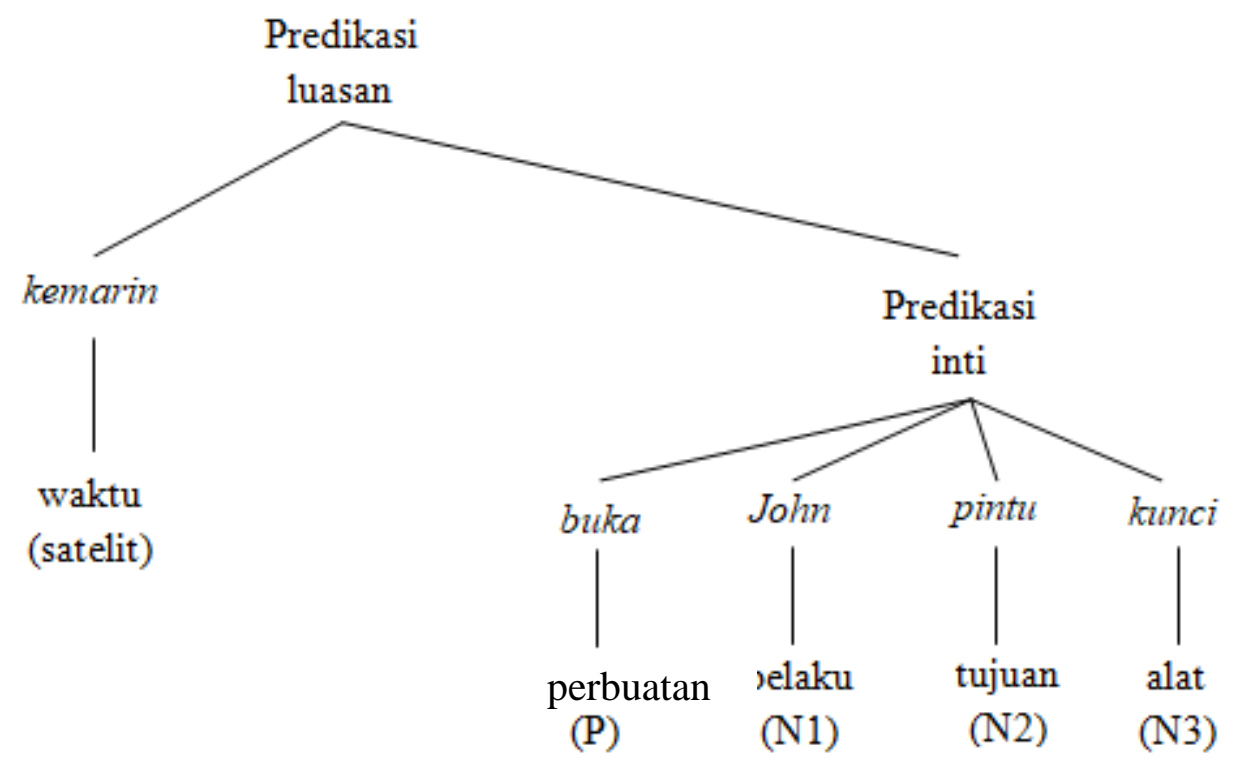

Bagan 2 contoh predikasi

Berdasarkan paparan di atas, dapat disimpulkan bahwa struktur proposisi adalah susunan atau pola yang terbentuk dari predikator $(\mathrm{P})$, argumen $(\mathrm{N})$, dan keterangan (satelit). Struktur proposisi yang tersusun atas predikator (P) dan argumen $(\mathrm{N})$ disebut predikasi inti. Sementara itu, predikasi inti yang mendapat tambahan keterangan (satelit), membentuk sebuah struktur proposisi yang dikenal dengan predikasi luasan.

\section{Makna Predikator}

Harimurti (1985:9) tentang relasi makna predikator, mengungkapkan bahwa makna predikator mencakup perbuatan, proses, posisi, keadaan, dan identitas. Predikator ini biasanya ber- kategori verba atau adjektiva. Akan tetapi, ada juga predikator yang tidak berkategori verba atau adjektiva atau yang biasa dikenal dengan zero (0) (Kridalaksana, 1985: 9)

Makna perbuatan mengacu pada setiap predikat yang melakukan sebuah tindakan. Makna proses mengacu pada setiap predikat yang merupakan rangkai-an tindakan, pembuatan, atau pengolah-an yang menghasilkan produk. Makna posisi mengacu pada setiap predikat yang bermakna letak ataupun kedudu-kan. Makna keadaan mengacu pada setiap predikat yang terkait dengan situasi ataupun suasana. Makna identitas mengacu pada setiap 
predikat yang menjelaskan ciri-ciri atau keadaan khusus argumen-argumennya.

Jadi, berdasarkan paparan di atas, dapat disimpulkan bahwa relasi makna antara predikator dan argumen adalah makna yang terbentuk karena adanya hubungan antara predikator dan argumen. Makna yang muncul pada predikator ini terbagi atas lima makna, yaitu makna perbuatan, proses, posisi, keadaan, dan identitas.

\section{Peran Argumen}

Argumen merupakan benda atau yang dibendakan dan berkategori nomina. Argumen-argumen itu secara fungsional ada dua jenis yaitu subjek dan objek (Verhaar, 1996: 166-167). Subjek adalah apa yang berada dalam keadaan yang diartikan oleh verba di tempat predikat, atau apa yang mengalami kejadian yang diartikan oleh verba (bervalensi satu, atau bervalensi lebih dari satu tetapi dalam bentuk pasif), atau apa yang melakukan hal-hal yang diartikan oleh verba. Sementara itu, objek adalah pihak yang mengalami tindakan yang diartikan oleh verba bervalensi dua.

Berkaitan dengan argumen, ada dua hal yang perlu diperhatikan berkaitan dengan fungsi sintaksisnya.

1. Argumen-argumen secara fungsional, adalah konstituen yang tidak terikat pada sifat semantis tertentu dari peserta yang bersangkutan. Misalnya, subjek verba dalam diatesis aktif adalah 'pelaku', sedangkan subjek verba dalam diatesis pasif adalah 'pengalam', maksudnya peserta yang mengalami apa yang diartikan oleh verba.

2. Argumen-argumen secara fungsional, adalah konstituen yang tidak terikat pada bentuk kategori nominal dari peserta yang bersangkutan. Contoh: a. (Tentang) usul ini akan dijelaskan nanti

b. (Untuk) dia diambilkan alat yang lain

Subjek dari (a) adalah (Tentang) usul ini, subjek ini dapat disertai preposisi tentang ataupun tidak. Begitu juga subjek dalam (b), bisa dia atau untuk dia.

Hubungan di antara tiap argumen dan predikator disebut peran. Dalam bahasa Indonesia terdapat peranperan sebagai berikut.

1. Penanggap: benda bernyawa yang bereaksi terhadap lingkungannya atau yang mengalami proses psikologis. Penanggap dapat pula berupa yang mengingini, yang mencintai, yang menghargai, atau yang menderita penghinaan, cemooh, dan sebagainya.

2. Pelaku: benda bernyawa atau tak bernyawa yang mendorong suatu proses atau yang bertindak.

3. Tokoh: benda bernyawa yang diterangkan oleh benda lain atau yang memerankan apa yang disebut predikator.

4. Pokok: benda tak bernyawa yang diterangkan oleh benda lain atau yang memerankan apa yang disebut predikator.

5. Ciri: benda yang menerangkan benda lain.

6. Penderita: benda bernyawa yang mengalami perubahan secara fisik atau yang berubah tempatnya atau letaknya. Penderita dapat pula berupa yang dimiliki, yang diperoleh, atau yang dipertukarkan.

7. Sasaran: benda tak bernyawa yang mengalami perubahan fisik atau yang berubah tempatnya atau letaknya.

8. Hasil: benda yang melengkapi atau mengkhususkan predikator atau yang menjadi hasil tindakan predikator. 
9. Pemeroleh: benda yang mendapat keuntungan dari predikator.

10. Ukuran: benda yang mengungkapkan banyaknya atau ukuran predikator.

11. Alat: benda tak bernyawa yang dipakai oleh pelaku untuk menyelesaikan suatu perbuatan atau mendorong suatu proses atau benda bernyawa atau tak bernyawa yang menimbulkan kondisi untuk terjadinya sesuatu.

12. Tempat: benda tempat predikator terjadi.

13. Asal tempat: tempat yang menjadi sumber predikator atau benda pemilik semula dalam tukarmenukar.

14. Jangkauan: batas lokasi predikator.

15. Cara: cara perbuatan.

16. Peserta: benda yang mengikuti pelaku.

17. Arah: batas kegiatan predikator.

18. Waktu: waktu terjadinya predikator.

19. Asal bahan : bahan terjadinya predikator.

Jadi, berdasarkan paparan di atas dapat disimpulkan bahwa peran argumen terbagi atas sembilan belas peran, yaitu: (1) Penanggap; (2) Pelaku; (3) Tokoh; (4) Pokok; (5) Ciri; (6) Penderita; (7) Sasaran; (8) Hasil; (9) Pemeroleh; (10) Ukuran; (11) Alat; (12) Tempat; (13) Asal tempat; (14) Jangkauan; (15) Cara; (16) Peserta; (17) Arah; (18) Waktu; dan (19) Asal bahan.

\section{Rancag Si Pitung}

Kata rancag (menurut ucapan orang Betawi pinggiran) atau rancak (menurut ucapan orang Betawi tengah/orang kota), sama artinya dengan pantun (Ruchiat, 2003: 156). Rancagan berarti pantunan. Cerita yang dibawakan dengan dipantunkan, disebut cerita rancagan, atau cukup disebut rancak atau rancag. Contoh rancagan berikut diambil sebagai cuplikan dari rancagan.

"Si Angkri", Jago Pasar Ikan, dibawakan oleh Samad Modo, Gandaria:

Kalo tiang puri dari tuakan

terang ngambil puri tukang badil jadi

Waktu dulu Angkri jadi jago Pasar ikan

Satu malam Angkri mencuri barang.

Kalo tukang besi dari Serang

kala tukang orim dari tanah lapang

Memang waktu itu si Angkri mencuri barang

Barangnya mau dikirim sama Bang Kasum centeng empang.

Pantun pada rancag disusun mengikuti jalur cerita yang sudah tetap. Suatu cerita dapat dipanjangkan penghidangannya dengan berbagai tambahan, misalnya dengan lawakan yang sering kali menyimpang dari cerita.Namun demikian tetap disenangi oleh penonton-nya. Rancag biasanya dihidangkan dengan iringan orkes gambang kromong, dengan sebutan Gambang Rancag.

Rancag Si Pitung merupakan sebuah rancag yang menceritakan tentang tokoh Betawi yang bernama Pitung. Dalam teks ini, dikisahkan tentang kehidupan seseorang bernama Pitung, yang diyakini sebagai buronan kompeni, karena ulahnya sebagai perampok. Si Pitung dikisahkan beberapa kali tertangkap, namun selalu bisa melarikan diri. Masyarakat mempercayai bahwa $\mathrm{Si}$ Pitung memiliki kekuatan sakti yang tidak seperti manusia pada umumnya. Semua kisah ini, dikisahkan melalui pantun yang dibawakan dengan iringan musik dari orkes gambang kromong. 


\section{METODE PENELITIAN}

Metode dalam penelitian ini yaitu metode deskriptif kualitatif dengan teknik analisis isi. Pengumpulan data dalam penelitian ini dilakukan dengan mengidentifikasi klausa yang terdapat di dalam teks syair Rancag Si Pitung dan mengklasifikasikannya. Langkahlangkah yang dilakukan dalam penelitian ini diperoleh menurut Miles dan Huberman, yaitu (Rohidi, 1992: 1920):

1. Reduksi Data

Peneliti membaca secara keseluruhan teks yang sudah ditentukan. Setelah isi teks tersebut dipahami secara keseluruhan, peneliti membaca kritis teks Rancag Si Pitung dalam rangka memperoleh penghayatan dan pemahaman terhadap seluruh ini teks. Peneliti membaca teks secara merinci, memilah-milah, menyeleksi dan menggolongkan/ mengelompokan klausa dari teks tersebut. Hal ini dilakukan agar memudahkan peneliti dalam menentukan struktur proposisi, relasi makna antara predikator dengan argumen, dan pembagian peran tiap-tiap argumen dari setiap klausa tersebut.

2. Penyajian data

Penyajian data analisis menggunakan Tabel Analisis Proposisi untuk dapat melihat struktur proposisi, makna predikator, serta peran argumen yang terdapat dalam teks syair Rancag Si Pitung.

3. Penarikan kesimpulan dilakukan selama proses penelitian berlangsung.

\section{HASIL DAN PEMBAHASAN}

Data penelitian ini adalah klausa dalam Rancag Si Pitung. Klausa tersebut termasuk di dalamnya struktur proposisi, makna predikator, dan peran argumen. Klausa yang diperoleh dari Rancag Si Pitung berjumlah 99 klausa. Data-data tersebut disajikan dalam bentuk tabel berikut:

Tabel 1 Struktur Proposisi dalam Rancag Si Pitung

\begin{tabular}{|c|c|c|}
\hline $\mathrm{NO}$ & STRUKTUR PROPOSISI & JUMLAH \\
\hline 1 & $\mathrm{P}+\mathrm{N}_{1}$ & 30 \\
\hline 2 & $\mathrm{P}+\mathrm{N}_{1}+\mathrm{N}_{2}$ & 39 \\
\hline 3 & $\mathrm{P}+\mathrm{N}_{1}+\mathrm{N}_{2}+\mathrm{N}_{3}$ & 5 \\
\hline 4 & $\mathrm{P}+\mathrm{N}_{1}+$ Satelit I & 3 \\
\hline 5 & $\mathrm{P}+\mathrm{N}_{1}+\mathrm{N}_{2}+$ Satelit I & 2 \\
\hline 6 & $P+N_{1}+N_{2}+N_{3}+$ Satelit I & - \\
\hline 7 & $\mathrm{P}+\mathrm{N}_{1}+$ Satelit II & 10 \\
\hline 8 & $\mathrm{P}+\mathrm{N}_{1}+\mathrm{N}_{2}+$ Satelit II & 1 \\
\hline 9 & $\mathrm{P}+\mathrm{N}_{1}+\mathrm{N}_{2}+\mathrm{N}_{3}+$ Satelit II & - \\
\hline 10 & $\mathrm{P}+\mathrm{N}_{1}+$ Satelit III & 1 \\
\hline 11 & $\mathrm{P}+\mathrm{N}_{1}+\mathrm{N}_{2}+$ Satelit III & 4 \\
\hline 12 & $\mathrm{P}+\mathrm{N}_{1}+\mathrm{N}_{2}+\mathrm{N}_{3}+$ Satelit III & - \\
\hline 13 & $\mathrm{P}+\mathrm{N}_{1}+$ Satelit I + Satelit II & 1 \\
\hline 14 & $\mathrm{P}+\mathrm{N}_{1}+\mathrm{N}_{2}+$ Satelit I + Satelit II & - \\
\hline 15 & $P+N_{1}+N_{2}+N_{3}+$ Satelit I + Satelit II & - \\
\hline 16 & $\mathrm{P}+\mathrm{N}_{1}+$ Satelit I + Satelit III & - \\
\hline 17 & $\mathrm{P}+\mathrm{N}_{1}+\mathrm{N}_{2}+$ Satelit I + Satelit III & - \\
\hline 18 & $P+N_{1}+N_{2}+N_{3}+$ Satelit I + Satelit III & - \\
\hline
\end{tabular}




\begin{tabular}{lll}
19 & $\mathrm{P}+\mathrm{N}_{1}+$ Satelit II + Satelit III & 3 \\
20 & $\mathrm{P}+\mathrm{N}_{1}+\mathrm{N}_{2}+$ Satelit II + Satelit III & - \\
21 & $\mathrm{P}+\mathrm{N}_{1}+\mathrm{N}_{2}+\mathrm{N}_{3}+$ Satelit II + Satelit III & - \\
22 & $\mathrm{P}+\mathrm{N}_{1}+$ Satelit I + Satelit II + Satelit III & - \\
23 & $\mathrm{P}+\mathrm{N}_{1}+\mathrm{N}_{2}+$ Satelit I + Satelit II + Satelit III & - \\
24 & $\mathrm{P}+\mathrm{N}_{1}+\mathrm{N}_{2}+\mathrm{N}_{3}+$ Satelit I + Satelit II + Satelit III & - \\
\hline
\end{tabular}

Keterangan:

- $\mathrm{P}=$ Predikator

- $\mathrm{N}_{1}=$ Nomina $1 /$ Argumen 1 - Satelit $\mathrm{I}=$ Ket. waktu

- $\mathrm{N}_{2}=$ Nomina $2 /$ Argumen 2 - Satelit II = Ket. tempat

- $\mathrm{N}_{3}=$ Nomina $3 /$ Argumen 3 - Satelit III= Ket. modus

Berdasarkan tabel di atas, diperoleh informasi mengenai struktur proposisi dalam klausa Rancag $S i$ Pitung. Struktur-struktur tersebut terdiri atas unsur: predikator $(\mathrm{P})$, argumen 1 $\left(\mathrm{N}_{1}\right)$, argumen $2\left(\mathrm{~N}_{2}\right)$, argumen $3\left(\mathrm{~N}_{3}\right)$, Satelit I/ keterangan waktu, Satelit II/ keterangan tempat, dan Satelit III/ keterangan modus. Unsur-unsur tersebut kemudian dirangkaikan hingga menjadi 24 rangkaian struktur.

Dari ke-24 rangkaian struktur proposisi tersebut, penulis menganalisis-nya satu per satu berdasarkan struktur proposisi, makna predikator, juga peran argumennya. Untuk lebih jelasnya, berikut adalah penjelasan dari setiap bagian tersebut.

\section{Struktur Proposisi dalam Rancag Si Pitung}

Pada struktur proposisi 1, ditemukan sebanyak 30 data. Data-data tersebut di antaranya adalah:
1. Pondok Kopi tempat pengapisan
2. Marunda Pulo tempat tujuan
3. Mak si Pitung ogah dimadu
4. Kampung Rawa Belong tempat dituju
5. Nasib apìs Pitung tuju keliling
6. Guru Na'ipin murid Guru Cit Pecenongan
7. Petani tertindas
8. (Pitung) Mendengar
9. Ji'ih dibunuh
10. (Ji'ih) diperangkap

Data-data tersebut merupakan data yang terdiri atas predikator dan satu argumen, sehingga stuktur proposisi yang terbentuk ialah $\mathrm{P}+\mathrm{N}_{1}$. Data-data tersebut merupakan bentuk terkecil klausa, yang terdiri atas subjek dan predikat saja.

Pada struktur proposisi 2, ditemukan sebanyak 39 data. Data-data tersebut di antaranya adalah:

1. Tiga pelor waja satu emas beneran cuman kaja Pitung rebah doangan

2. Schout Hijne punya pimpinan

3. (Mak si Pitung) Becere ema laki sudahlah kudu

4. Pitung pitik tumbuh bermain gundu

5. Kewajiban pokok mengangon kambing

6. Hasil jualan dirampas maling

7. Kemayoran dituju dari Paal Merah

8. (Pitung) Ketemu Guru Na'ipin ahli tareqah

9. Tarekat Betawi memang selalu berendengan sama maen pukulan dan kekebalan badan

10. Tapi Pitung amalkan fa'ie

11. Harta musuh halal buat urusan sabili

12. Perang sabil lawan kumpeni

13. Pitung ambil peran semacam bendahari

Data-data tersebut merupakan data yang terdiri atas predikator dan dua argumen, sehingga stuktur proposisi yang terbentuk ialah $\mathrm{P}+\mathrm{N}_{1}+\mathrm{N}_{2}$. Data- 
data tersebut merupakan bentuk klausa yang atas subjek, predikat, dan objek.

Pada struktur proposisi 3, ditemukan sebanyak lima data. Data tersebut di antaranya adalah:

Langgar Gang Kingkit dia punya perguruan

Data tersebut merupakan data yang terdiri atas predicator dan tiga argumen, sehingga stuktur proposisi yang terbentuk ialah $\mathrm{P}+\mathrm{N}_{1}+\mathrm{N}_{2}+\mathrm{N}_{3}$. Data tersebut merupakan bentuk klausa yang terdiri atas subjek, predikat, objek langsung, dan objek tidak langsung.

Pada struktur proposisi 4, ditemukan sebanyak tiga data. Data tersebut di antaranya adalah:

Malah sesudahnya Hijne ketawa cekikikan

Data tersebut merupakan data yang terdiri atas predikator, satu argumen, dan keterangan waktu, sehingga stuktur proposisi yang ialah $\mathrm{P}+$ $\mathrm{N}_{1}+$ Satelit I. Data tersebut merupakan bentuk klausa yang terdiri atas subjek, predikat, dan keterangan waktu.

Pada struktur proposisi 5, ditemukan sebanyak dua data. Data tersebut di antaranya adalah:

Pitung temui ajal di perjalanan

Data tersebut merupakan data yang terdiri atas predikator, dua argumen, dan keterangan waktu, sehingga stuktur proposisi yang terbentuk ialah $\mathrm{P}+\mathrm{N}_{1}+\mathrm{N}_{2}+$ Satelit I. Data tersebut merupakan bentuk klausa yang masing-masing terdiri atas subjek, predikat, objek, dan keterangan waktu.

Pada struktur proposisi 7, ditemukan sebanyak sepuluh data. Datadata tersebut di antaranya adalah:

1. Empat pelor nembus di badan

2. Dia sukanya maen di pesisiran

3. Pitung takut pulang ke rumah
Data-data tersebut merupakan data yang terdiri atas predikator, satu argumen, dan keterangan tempat, sehingga struktur proposisi yang terbentuk ialah $\mathrm{P}+\mathrm{N}_{1}+$ Satelit II. Data tersebut merupakan bentuk klausa yang masing-masing terdiri atas subjek, predikat, dan keterangan tempat.

Pada struktur proposisi 8, ditemukan sebanyak satu data. Data tersebut adalah:

Marunda Pulo Kali besar Bandengan Pitung punya daerah rampokan

Data tersebut merupakan data yang terdiri atas predikator, dua argumen, dan keterangan tempat, sehingga stuktur proposisi yang terbentuk ialah $\mathrm{P}+\mathrm{N}_{1}+\mathrm{N}_{2}+$ Satelit II. Data tersebut merupakan bentuk klausa yang terdiri atas subjek, predikat, objek, dan keterangan tempat.

Pada struktur proposisi 10, ditemukan sebanyak satu data. Data tersebut adalah:

Bawa pulisi bangsa selusinan

Data tersebut merupakan data yang terdiri atas predikator, satu argumen, dan keterangan modus, sehingga stuktur proposisi yang terbentuk pastilah $\mathrm{P}+\mathrm{N}_{1}+$ Satelit III. Data tersebut merupakan bentuk klausa yang terdiri atas subjek, predikat, dan keterangan modus.

Pada struktur proposisi 11, ditemukan sebanyak empat data. Data tersebut di antaranya adalah:

Pasti Mak sama Engkong pada marah

Data tersebut merupakan data yang terdiri atas predikator, dua argumen, dan keterangan modus, sehingga stuktur proposisi yang terbentuk ialah $\mathrm{P}+\mathrm{N}_{1}+\mathrm{N}_{2}+$ Satelit III. Data tersebut merupakan bentuk klausa yang terdiri atas subjek, predikat, objek, dan keterangan modus. 
Pada struktur proposisi 13, ditemukan sebanyak satu data. Data tersebut adalah:

(Pitung) Lahir di Cikoneng Tangerang punya bilangan dari tahun 1896 punya hitungan

Data tersebut merupakan data yang terdiri atas predikator, satu argumen, keterangan waktu, dan keterangan tempat, sehingga stuktur proposisi yang terbentuk ialah $\mathrm{P}+\mathrm{N}_{1}+$ Satelit I + Satelit II. Data tersebut merupakan bentuk klausa yang terdiri atas subjek, predikat, keterangan waktu, dan keterangan tempat.

Pada struktur proposisi 19, ditemukan sebanyak tiga data. Data tersebut di antaranya adalah:

Kalau (kambing) gemuk jual di pasar zonder keliling
Data tersebut merupakan data yang terdiri atas predikator, satu argumen, keterangan tempat, dan keterangan modus, sehingga stuktur proposisi yang terbentuk ialah $\mathrm{P}+\mathrm{N}_{1}+$ Satelit II + Satelit III. Data tersebut merupakan bentuk klausa yang terdiri atas subjek, predikat, keterangan tempat, dan keterangan modus.

Ternyata bentuk struktur proposisi (6), (9), (12), (14), (15), (16), (17), (18), (20), (21), (22), (23), dan (24), tidak ditemukan pada data. Jadi, dari 24 bentuk struktur proposisi, hanya ada 11 bentuk struktur proposisi yang terdapat pada data. Ke-11 bentuk struktur proposisi inilah yang nantinya akan dianalisis dan diungkap relasi makna dan pembagian peran dari masingmasing argumennya.

Berdasarkan hasil analisis, dapat disajikan tabel hasil analisis sebagai berikut:

Tabel 2 Rekapitulasi Hasil Analisis Struktur Proposisi dalam Rancag Si Pitung

\begin{tabular}{clc}
\hline NO & \multicolumn{1}{c}{ Struktur Proposisi } & Jumlah \\
\hline 1 & \multicolumn{1}{c}{$\mathrm{P}+\mathrm{N}_{1}$} & 30 \\
& & 39 \\
\hline 2 & $\mathrm{P}+\mathrm{N}_{1}+\mathrm{N}_{2}$ & 5 \\
\hline 3 & $\mathrm{P}+\mathrm{N}_{1}+\mathrm{N}_{2}+\mathrm{N}_{3}$ & 3 \\
\hline 4 & $\mathrm{P}+\mathrm{N}_{1}+$ Prf. I & 2 \\
\hline 5 & $\mathrm{P}+\mathrm{N}_{1}+\mathrm{N}_{2}+$ Prf. I & 10 \\
\hline 6 & $\mathrm{P}+\mathrm{N}_{1}+$ Prf. II & 1 \\
\hline 7 & $\mathrm{P}+\mathrm{N}_{1}+\mathrm{N}_{2}+$ Prf. II & 1 \\
\hline 8 & $\mathrm{P}+\mathrm{N}_{1}+$ Prf. III & 4 \\
\hline 9 & $\mathrm{P}+\mathrm{N}_{1}+\mathrm{N}_{2}+$ Prf. III & 1 \\
\hline 10 & $\mathrm{P}+\mathrm{N}_{1}+$ Prf. I + Prf. II & 3 \\
\hline 11 & $\mathrm{P}+\mathrm{N}_{1}+$ Prf. II + Prf. III & 99 \\
\hline & Total &
\end{tabular}

Keterangan:

- $\mathrm{P}=$ Predikator

- $\mathrm{N}_{1}=$ Nomina $1 /$ Argumen 1 - Satelit I = Ket. waktu

$-\mathrm{N}_{2}=$ Nomina $2 /$ Argumen 2 - Satelit II = Ket. tempat

- $\mathrm{N}_{3}=$ Nomina 3 / Argumen 3 - Satelit III= Ket. modus

Dari tabel di atas, dapat disimpulkan bahwa klausa-klausa tersebut terbagi atas 30 klausa berstruktur proposisi $\mathrm{P}+\mathrm{N}_{1}, 39$ klausa berstruktur propsisi $\mathrm{P}+\mathrm{N}_{1}+\mathrm{N}_{2}, 5$ klausa berstruktur proposisi $\mathrm{P}+\mathrm{N}_{1}+\mathrm{N}_{2}+\mathrm{N}_{3}$, 
3 klausa berstruktur proposisi $\mathrm{P}+\mathrm{N}_{1}+$ Satelit I, 2 klausa berstruktur proposisi $\mathrm{P}+\mathrm{N}_{1}+\mathrm{N}_{2}+$ Satelit I, 10 klausa berstruktur proposisi $\mathrm{P}+\mathrm{N}_{1}+$ Satelit II, 1 klausa berstruktur proposisi $\mathrm{P}+\mathrm{N}_{1}+$ $\mathrm{N}_{2}+$ Satelit II, 1 klausa berstruktur proposisi $\mathrm{P}+\mathrm{N}_{1}+$ Satelit III, 4 klausa berstruktur proposisi $\mathrm{P}+\mathrm{N}_{1}+\mathrm{N}_{2}+$ Satelit III, 1 klausa berstruktur proposisi $\mathrm{P}+\mathrm{N}_{1}+$ Satelit I + Satelit II, dan 3 klausa berstruktur proposisi $\mathrm{P}+\mathrm{N}_{1}+$ Satelit II + Satelit III.

Berdasarkan data tersebut, dapat diketahui bahwa struktur proposisi yang paling banyak muncul adalah struktur proposisi $\mathrm{P}+\mathrm{N}_{1}+\mathrm{N}_{2}$ dengan kemunculan 39,39\% dari jumlah keseluruhan data yang ada. Kedua adalah struktur proposisi $\mathrm{P}+\mathrm{N}_{1}$ dengan kemunculan 30,30\% dari jumlah data. Dari kedua kemunculan terbesar tersebut, terlihat bahwa struktur proposisi tanpa satelit adalah yang paling banyak digunakan. Dengan demikian, dapat disimpulkan bahwa Rancag Si Pitung lebih dominan menggunakan struktur proposisi berpredikasi inti.

\section{Makna Predikator dalam Rancag Si Pitung}

Hubungan antara predikator dan argumen, akan menghasilkan sebuah makna. Makna tersebut bisa berupa perbuatan, proses, posisi, keadaan, dan identitas. Relasi makna ini tergantung dari argumen-argumen yang ada pada setiap struktur proposisi. Adapun contoh-contoh dari relasi makna tersebut adalah sebagai berikut:

1. Perbuatan

$$
\text { Contoh relasi makna }
$$
perbuatan dapat kita temui pada klausa:

Tapi dipegat kumpeni di jalanan

\section{Analisis}

Pada klausa di atas, dipegat yang berkategori verba bertindak sebagai predikator (P). Kata kumpeni yang berkategori nomina bertindak sebagai argumen, sedangkan di jalanan merupakan keterangan tempat yang bertindak sebagai satelit.

Kesimpulan

Melihat hubungan antara predikator dan argumennya, maka predikator dalam hal ini memiliki makna perbuatan.

2. Proses

Contoh relasi makna proses dapat kita temui pada klausa:

Kalau (kambing) gemuk jual di pasar zonder keliling

Analisis

Pada klausa di atas, jual yang berkategori verba bertindak sebagai predikator $(\mathrm{P})$. (Kambing) gemuk yang berkategori nomina bertindak sebagai argumen. Pasar Zonder keliling merupakan keterangan tempat sedangkan kalau merupakan keterangan modus yang keduanya sama-sama bertindak sebagai unsur satelit.

\section{Kesimpulan}

Melihat hubungan antara predikator dan argumennya, maka predikator dalam hal ini memiliki makna proses.

3. Posisi

Contoh relasi makna posisi tidak ditemui pada data. Hal ini disebabkan karena relasi makna ini terbatas pada relasi makna yang menunjukkan posisi, letak, dan keberadaan argumennya.

4. Keadaan

Contoh relasi makna keadaan dapat kita temui pada klausa: 


\begin{abstract}
Empat pelor nembus di badan Analisis

Pada klausa di atas, nembus yang berkategori verba bertindak sebagai predikator (P). Empat pelor yang berkategori nomina bertindak sebagai argumen, sedangkan di badan merupakan keterangan tempat yang bertindak sebagai unsur satelit.

\section{Kesimpulan}

Melihat hubungan antara predikator dan argumennya, maka predikator dalam hal ini memiliki makna keadaan.
\end{abstract}

5. Identitas

Contoh relasi makna identitas dapat kita temui pada klausa:

$\quad$ Pondok Kopi tempat
pengapisan
Analisis

Pada klausa di atas, tempat pengapisan yang berkategori adjektiva bertindak sebagai predikator (P). Pondok Kopi yang berkategori nomina bertindak sebagai argumen.

Kesimpulan

Melihat hubungan antara predikator dan argumennya, maka predikator dalam hal ini memiliki makna identitas.

Hasil analisis relasi makna antara predikator dengan argumen terangkum dalam tabel berikut:

\section{Tabel 3 Rekapitulasi Hasil Analisis Makna Predikator dalam Rancag Si Pitung

\begin{tabular}{l|c|c|c|c|c|c} 
Makna Predikator & Perbuatan & Keadaan & Proses & Identitas & Posisi & Total data \\
\hline Jumlah data & 66 & 23 & 4 & 6 & - & 99
\end{tabular} \\ Berdasarkan tabel data di atas maka dapat disimpulkan bahwa dari 99 data yang terdapat dalam Rancag $\mathrm{Si}$ \\ Peran Argumen dalam Rancag Si Pitung} Pitung, terdapat 66 predikator bermakna perbuatan, 23 predikator bermakna keadaan, 4 predikator bermakna proses, dan 6 predikator bermakna identitas. Sementara itu, tidak ada data predikator bermakna posisi yang ditemukan dalam data tersebut.

Berdasarkan data tersebut, dapat diketahui bahwa makna predikator yang paling banyak muncul adalah predikator bermakna perbuatan dengan kemunculan $66,67 \%$ dari jumlah keseluruhan data yang ada. Kemunculan kedua terbanyak adalah predikator bermakna keadaan dengan kemunculan $23,23 \%$ dari jumlah data. Dari kedua kemunculan terbesar tersebut, terlihat bahwa predikator bermakna perbuatan adalah yang paling banyak digunakan. Dengan demikian, dapat disimpulkan bahwa Rancag Si Pitung lebih dominan menggunakan klausa verba.

Hubungan di antara tiap argumen dan predikator disebut peran. Dalam bahasa Indonesia, peran-peran tersebut terbagi atas 19 peran yaitu penanggap, pelaku, tokoh, pokok, cirri, penderita, sasaran, hasil, pemeroleh, ukuran, alat, tempat, asal tempat, jangkauan, cara, peserta, arah, waktu, asal bahan.

Contoh:

1. Penanggap

Contoh peran penanggap terdapat pada klausa: Analisis
Bawa pulisi bangsa selusinan
Pada klausa tersebut, pulisi, sebagai $\mathrm{N}_{1}$, menjadi penanggap dari predikator.
Kesimpulan
$\mathrm{N}_{1}$ dalam hal ini berperan sebagai penanggap. 
2. Pelaku

Contoh peran pelaku terdapat pada klausa:

Tiga pelor waja satu emas beneran cuman kaja Pitung rebah doangan

Analisis

Pada klausa tersebut, tiga pelor waja satu emas beneran, sebagai $\mathrm{N}_{1}$, menjadi pelaku dari predikator.

Kesimpulan

$\mathrm{N}_{1}$ dalam hal ini berperan sebagai pelaku.

3. Tokoh

Contoh peran tokoh terdapat pada klausa:

Pitung besar di Kebayuran

Analisis

Pada klausa tersebut, Pitung, sebagai $\mathrm{N}_{1}$, menjadi tokoh dari predikator.

Kesimpulan

$\mathrm{N}_{1}$ dalam hal ini berperan sebagai tokoh.

4. Pokok

Contoh peran pokok terdapat pada klausa:

Pondok Kopi tempat pengapisan

Analisis

Pada klausa tersebut, Pondok Kopi, sebagai $\mathrm{N}_{1}$, menjadi pokok informasi dari predikator.

Kesimpulan

$\mathrm{N}_{1}$ dalam hal ini berperan sebagai pokok.

5. Ciri pada klausa:

Contoh peran ciri terdapat (Pitung) Ketemu Guru Na'ipin ahli tareqah
Analisis

Pada klausa tersebut, Guru Na'ipin ahli tareqah, sebagai $\mathrm{N}_{2}$, menjadi ciri dari predikator yang dilakukan oleh $\mathrm{N}_{1}$.

Kesimpulan

$\mathrm{N}_{2}$ dalam hal ini berperan sebagai ciri.

6. Penderita

Contoh peran penderita terdapat pada klausa:

Tiga pelor waja satu emas beneran cuman kaja Pitung rebah doangan

Analisis

Pada klausa tersebut, Pitung, sebagai $\mathrm{N}_{2}$, menjadi penderita dari predikator yang dilakukan oleh $\mathrm{N}_{1}$.

Kesimpulan

$\mathrm{N}_{2}$ dalam hal ini berperan sebagai penderita.

7. Sasaran

Contoh peran sasaran terdapat pada klausa:

Duit keras dan permata emas-emasan Dia jarah bersama Ji'ih bedua'an

Analisis

Pada klausa tersebut, Duit keras dan permata emas-emasan, sebagai $\mathrm{N}_{2}$, menjadi sasaran dari predikator yang dilakukan oleh $\mathrm{N}_{1}$. Kesimpulan

$\mathrm{N}_{2}$ dalam hal ini berperan sebagai sasaran.

8. Hasil

Contoh peran sasaran terdapat pada klausa:

Langgar Gang Kingkit dia punya perguruan

Analisis

Pada klausa tersebut, perguruan, sebagai $\mathrm{N}_{2}$, menjadi hasil dari predikator yang dilakukan oleh $\mathrm{N}_{1}$. 
Kesimpulan

$\mathrm{N}_{2}$ dalam hal ini berperan sebagai hasil.

9. Pemeroleh

Contoh peran pemeroleh terdapat pada klausa:

\section{kambing}

Kewajiban pokok mengangon

\section{Analisis}

Pada klausa tersebut, kambing, sebagai $\mathrm{N}_{2}$, menjadi pemeroleh dari predikator yang dilakukan oleh $\mathrm{N}_{1}$.

Kesimpulan

$\mathrm{N}_{2}$ dalam hal ini berperan sebagai pemeroleh.

10. Ukuran

Contoh peran ukuran terdapat pada klausa:

Satu kali Pitung tertangkap Analisis

Pada klausa tersebut, satu kali, sebagai $\mathrm{N}_{2}$, menjadi ukuran dari predikator yang dilakukan oleh $\mathrm{N}_{1}$.

Kesimpulan

$\mathrm{N}_{2}$ dalam hal ini berperan sebagai ukuran.

11. Alat

Contoh peran alat terdapat pada klausa:

\section{gundu}

Pitung pitik tumbuh bermain

Analisis

Pada klausa tersebut, gundu, sebagai $\mathrm{N}_{2}$, menjadi alat dari predikator yang dilakukan oleh $\mathrm{N}_{1}$.

Kesimpulan

$\mathrm{N}_{2}$ dalam hal ini berperan sebagai alat.

\section{Tempat}

Contoh peran tempat terdapat pada klausa:
Langgar Gang Kingkit dia punya perguruan

Analisis

Pada klausa tersebut, Langgar Gang Kingkit, sebagai $\mathrm{N}_{3}$, menjadi tempat dari predikator.

Kesimpulan

$\mathrm{N}_{3}$ dalam hal ini berperan sebagai tempat.

13. Asal Tempat

Contoh peran asal tempat terdapat pada klausa:

\section{Merah}

Kemayoran dituju dari Paal

Analisis

Pada klausa tersebut, Paal Merah, sebagai $\mathrm{N}_{2}$, menjadi asal tempat dari predikator.

Kesimpulan

$\mathrm{N}_{2}$ dalam hal ini berperan sebagai asal tempat.

\section{Jangkauan}

Contoh peran jangkauan terdapat pada klausa:

Itu jaman banyak

pemberontakan petani Tambun

Ciomas Cilegon Condet Tana

Tinggi

Analisis

Pada klausa tersebut, Tambun

Ciomas Cilegon Condet Tana

Tinggi, sebagai $\mathrm{N}_{2}$, menjadi jangkauan dari predikator.

Kesimpulan

$\mathrm{N}_{2}$ dalam hal ini berperan sebagai jangkauan.

15. Cara

Contoh peran cara terdapat pada klausa:

Aturannya ini pegangan bela diri tak boleh digunakan buat jual aksi 


\section{Analisis}

Pada klausa tersebut, jual aksi, sebagai $\mathrm{N}_{2}$, menjadi cara dari predikator.

\section{Kesimpulan}

$\mathrm{N}_{2}$ dalam hal ini berperan sebagai cara.

16. Peserta pada:

Contoh peran peserta terdapat pada marah

Pasti Mak sama Engkong Analisis

Pada klausa tersebut, Engkong, sebagai $\mathrm{N}_{2}$, menjadi peserta $\mathrm{N}_{1}$ dari predikator.

Kesimpulan

$\mathrm{N}_{2}$ dalam hal ini berperan sebagai peserta.

17. Arah

Contoh peran arah terdapat pada klausa:

Kemayoran dituju dari Paal Merah

Analisis

Pada klausa tersebut, Kemayoran, sebagai $\mathrm{N}_{1}$, menjadi arah tujuan dari predikator.

\section{Kesimpulan}

$\mathrm{N}_{1}$ dalam hal ini berperan sebagai arah.

18. Waktu

Contoh peran waktu tidak terdapat pada data. Hal ini disebabkan peran ini digunakan untuk argumen yang merupakan penentu waktu dari predikator. Pada data, klausa semacam itu tidak ditemukan, sehingga peran tersebut pun tidak digunakan dalam klausa pada data.

19. Asal Bahan

Contoh peran asal bahan tidak terdapat pada data. Hal ini disebabkan peran ini digunakan untuk argumen yang merupakan bahan asal dari sebuah argumen lain. Pada data, klausa semacam itu tidak ditemukan, sehingga peran tersebut pun tidak digunakan dalam klausa pada data.

Hasil analisis pembagian peran pada tiap-tiap argumen terangkum dalam tabel berikut:

Tabel 4 Rekapitulasi Hasil Analisis Peran Argumen dalam Rancag Si Pitung

\begin{tabular}{c|ccc|c}
\hline PERAN & N1 & N2 & N3 & $\begin{array}{c}\text { TOTAL } \\
\text { PERAN }\end{array}$ \\
\hline b & 17 & 3 & 1 & 21 \\
c & 43 & 3 & - & 46 \\
\hline d & 6 & 1 & - & 7 \\
\hline $\mathbf{e}$ & 25 & 9 & - & 34 \\
$\mathbf{f}$ & 4 & 2 & - & 3 \\
\hline $\mathbf{g}$ & 1 & 1 & - & 10 \\
h & - & 2 & - & 3 \\
$\mathbf{i}$ & 1 & 4 & - & 5 \\
$\mathbf{j}$ & - & 2 & 1 & 3 \\
\hline
\end{tabular}




\begin{tabular}{c|ccc|c}
\hline $\mathbf{k}$ & - & 2 & - & 2 \\
$\mathbf{l}$ & - & - & 1 & 1 \\
$\mathbf{m}$ & - & 3 & - & 3 \\
$\mathbf{n}$ & - & 1 & - & 1 \\
$\mathbf{0}$ & - & 2 & - & 2 \\
$\mathbf{p}$ & - & 7 & 1 & 8 \\
$\mathbf{q}$ & 1 & 3 & - & 4 \\
$\mathbf{r}$ & - & - & - & 0 \\
$\mathbf{S}$ & - & - & - & 0 \\
\hline TOTAL & 99 & 51 & 5 & 155 \\
ARGUMEN & & & & \\
\hline
\end{tabular}

Keterangan:

a. penanggap; b. pelaku; c. tokoh; d. pokok; e. ciri; f. penderita; g. sasaran;

h. hasil; i. pemeroleh; j. ukuran; k. alat; l. tempat; m. asal tempat;

n. jangkauan; o. cara; p. peserta; q. arah; r. waktu; s. asal bahan.

Berdasarkan tabel data di atas maka dapat disimpulkan bahwa dari 155 argumen yang terdapat dalam Rancag $\mathrm{Si}$ Pitung, terdapat 21 argumen berperan sebagai penanggap, 46 argumen berperan sebagai pelaku, 7 argumen berperan sebagai tokoh, 34 argumen berperan sebagai pokok, 3 argumen berperan sebagai ciri, 10 argumen berperan sebagai penderita, 3 argumen berperan sebagai sasaran, 2 argumen berperan sebagai hasil, 5 argumen berperan sebagai pemeroleh, 3 argumen berperan sebagai ukuran, 2 argumen berperan sebagai alat, 1 argumen berperan sebagai tempat, 3 argumen berperan sebagai asal tempat, 1 argumen berperan sebagai jangkauan, 2 argumen berperan sebagai cara, 8 argumen berperan sebagai peserta, 4 argumen berperan sebagai arah, serta tidak ada argumen berperan sebagai waktu dan asal bahan yang ditemukan.

Berdasarkan data tersebut, dapat diketahui bahwa peran argumen yang paling banyak muncul adalah argumen yang berperan sebagai pelaku dengan kemunculan 29,68\% dari jumlah keseluruhan data yang ada. Kemunculan terbanyak kedua adalah argumen yang berperan sebagai pokok dengan kemunculan $21,93 \%$ dari jumlah data. Dari kedua kemunculan terbesar tersebut, terlihat bahwa peran pelaku merupakan peran yang paling banyak digunakan. Dengan demikian, dapat disimpulkan bahwa Rancag Si Pitung lebih dominan mengungkap subjek dalam konstruksinya.

\section{SIMPULAN}

Berdasarkan hasil penelitian yang telah dilakukan, maka dapat ditarik beberapa simpulan sebagai berikut:

1. Dari 99 konstruksi gramatikal yang ada pada Rancag Si Pitung, disimpulkan bahwa terdapat 30 struktur proposisi $\mathrm{P}+\mathrm{N}_{1}, 39$ struktur propsisi $\mathrm{P}+\mathrm{N}_{1}+\mathrm{N}_{2}, 5$ struktur proposisi $\mathrm{P}+\mathrm{N}_{1}+\mathrm{N}_{2}+\mathrm{N}_{3}$, 3 struktur proposisi $\mathrm{P}+\mathrm{N}_{1}+$ Satelit I, 2 struktur proposisi $\mathrm{P}+\mathrm{N}_{1}+\mathrm{N}_{2}+$ Satelit I, 10 struktur proposisi $\mathrm{P}+$ $\mathrm{N}_{1}+$ Satelit II, 1 struktur proposisi $\mathrm{P}$ $+\mathrm{N}_{1}+\mathrm{N}_{2}+$ Satelit II, 1 struktur proposisi $\mathrm{P}+\mathrm{N}_{1}+$ Satelit III, 4 struktur proposisi $\mathrm{P}+\mathrm{N}_{1}+\mathrm{N}_{2}+$ 
Satelit III, 1 struktur proposisi $\mathrm{P}+$ $\mathrm{N}_{1}+$ Satelit I + Satelit II, dan 3 struktur proposisi $\mathrm{P}+\mathrm{N}_{1}+$ Satelit II + Satelit III.

Berdasarkan data tersebut, dapat diketahui bahwa struktur proposisi yang paling banyak muncul adalah struktur proposisi $\mathrm{P}$ $+\mathrm{N}_{1}+\mathrm{N}_{2}$ dengan kemunculan 39,39\% dari jumlah keseluruhan data yang ada. Kemunculan kedua terbanyak adalah struktur proposisi $\mathrm{P}+\mathrm{N}_{1}$ dengan kemunculan 30,30\% dari jumlah data. Dari kedua kemunculan terbesar tersebut, terlihat bahwa struktur proposisi tanpa satelit adalah yang paling banyak digunakan. Dengan demikian, dapat disimpul-kan bahwa Rancag Si Pitung lebih dominan menggunakan struktur proposisi berpredikasi inti.

2. Dari 99 data yang terdapat dalam Rancag Si Pitung, terdapat 66 predikator bermakna perbuatan, 23 predikator bermakna keadaan, 4 predikator bermakna proses, dan 6 predikator bermakna identitas. Sementara itu, tidak ada data predikator bermakna posisi yang ditemukan dalam data tersebut.

Berdasarkan data tersebut, dapat diketahui bahwa makna predikator yang paling banyak muncul adalah predikator bermakna perbuatan dengan kemunculan $66,67 \%$ dari jumlah keseluruhan data yang ada. Kemunculan kedua terbanyak adalah predikator bermakna keadaan dengan kemunculan $23,23 \%$ dari jumlah data. Dari kedua kemunculan terbesar tersebut, ter-lihat bahwa predikator bermakna perbuatan adalah yang paling banyak digunakan. Dengan demikian, dapat disimpulkan bahwa
Rancag Si Pitung lebih dominan menggunakan klausa verba.

3. Dari 155 argumen yang ada dalam Rancag Si Pitung, terdapat 21 argumen berperan sebagai penanggap, 46 argumen berperan sebagai pelaku, 7 argumen berperan sebagai tokoh, 34 argumen berperan sebagai pokok, 3 argumen berperan sebagai ciri, 10 argumen berperan sebagai penderita, 3 argumen berperan sebagai sasaran, 2 argumen berperan sebagai hasil, 5 argumen berperan sebagai pemeroleh, 3 argumen berperan sebagai ukuran, 2 argumen berperan sebagai alat, 1 argumen berperan sebagai tempat, 3 argumen berperan sebagai asal tempat, 1 argumen berperan sebagai jangkauan, 2 argumen berperan sebagai cara, 8 argumen berperan sebagai peserta, 4 argumen berperan sebagai arah, serta tidak ada argumen berperan sebagai waktu dan asal bahan yang ditemukan.

Berdasarkan data tersebut, dapat diketahui bahwa peran argumen yang paling banyak muncul adalah argumen yang berperan sebagai pelaku dengan kemunculan $29,68 \%$ dari jumlah keseluruhan data yang ada. Kemunculan terbanyak kedua adalah argumen yang berperan sebagai pokok dengan kemunculan $21,93 \%$ dari jumlah data. Dari kedua kemunculan terbesar tersebut, ter-lihat bahwa peran pelaku merupakan peran yang paling banyak diguna-kan. Dengan demikian, dapat di-simpulkan bahwa Rancag Si Pitung lebih dominan mengungkap pelaku dalam konstruksinya.

Dari hasil yang telah diperoleh, maka disarankan perlu adanya penelitian lanjutan mengenai proposisi 
pada teks lain. Hal tersebut dapat dijadikan acuan untuk mengembangkan ilmu pengetahu-an khususnya ilmu linguistik, dan pemertahanan warisan budaya, khusus-nya dalam hal ini ialah seni budaya Betawi.

Rancag merupakan sebuah warisan budaya Betawi yang perlu dijaga kelestariannya secara terusmenerus dan berkesinambungan. Dengan adanya pe-nelitian ini, diharapkan generasi muda dapat memahami proposisi yang ada di dalam sebuah rancag dan meng-aplikasikannya dalam rangka pe-mertahanan warisan budaya Indonesia pada umumnya.

\section{DAFTAR PUSTAKA}

Alwi, H. dkk. (2003). Tata Bahasa Baku Bahasa Indonesia. Jakarta: Pusat Bahasa dan Balai Pustaka

Arifuddin. (2010). Neuropsikolinguistik. Jakarta: RajaGrafindo Persada

Chaer, A. (2007). Linguistik Umum. Jakarta: Rineka Cipta (2009). Kamus Dialek Jakarta Edisi Revisi. Jakarta: Masup Jakarta

. (2009). Psikolinguistik

Kajian Teoritik. Jakarta: Rineka Cipta

Gleason, J. B

(1993). Psycholinguistics. America: Harcourt Brace Jovanovich College Publishers

P., Achmad H. (2002). Sintaksis Bahasa Indonesia. Jakarta: Manasco Offset

Kridalaksana, H. dkk. (1985). Tata Bahasa Deskriptif Bahasa
Indonesia: Sintaksis. Jakarta: P3B Debdikbud

(2011). Kamus

Linguistik Edisi Keempat.

Jakarta: Gramedia Pustaka

Utama

Parera, J. D. (1991). Sintaksis. Jakarta: Gramedia Pustaka Utama

Rohidi, T. (1992). Analisis Data Kualitatif. Jakarta: Universitas Indonesia - Press

Ruchiat, R. dkk. (2003). Ikhtisar Kesenian Betawi. Jakarta: Dinas Kebudayaan dan Permuseuman Propinsi DKI Jakarta

Saidi, R. (2008). Lagu Pesisiran Puisipuisi Betawi. Cetakan Pertama. Jakarta: Bukupop-Badan Pemberdayaan Budaya Betawi

Sopandi, A dkk. (2000). Gambang Rancag. Jakarta: Dinas Kebudayaan DKI Jakarta

Tarigan, H. G. (1990). Pengajaran Tata Bahasa Kasus. Bandung: Angkasa

Verhaar, J. W. M. (1996). Asas-Asas Linguistik Umum. Yogyakarta: Gajah Mada University Press

Sudaryat, Y. (1963-1987). "Struktur Wacana dan Makna Kalimat dalam Gamitan Wacana". Dalam http://file.upi.edu/direktori/fpbs/ jur. pend. bahasa daerah/1963 02101987031-

yayat_sudaryat/struktur_wacana _dan_makna/kalimat_dalam_ga mitan_wacana.pdf diunduh pada 03 Mei 2012 pukul 15.29 WIB 